\title{
Effect of terroir on the phenolic compounds of Muscat of Bornova Wines from 3 different sub-regions of Aegean, Turkey
}

\author{
Selin N. Yabaci Karaoğlan ${ }^{1}$, Zeynep Dilan Çelik ${ }^{2}$, Merve Darici², Haşim Kelebek ${ }^{1}$, Hüseyin Erten², Burçak Işçi ${ }^{3}$, \\ Ahmet Altindişli ${ }^{3}$, and Turgut Cabaroglu ${ }^{2}$ \\ ${ }^{1}$ Adana Science and Technology University, Faculty of Engineering and Natural Sciences, Food Engineering Department, \\ Adana, Turkey \\ ${ }^{2}$ Cukurova University, Agriculture Faculty, Food Engineering Department, Adana, Turkey \\ ${ }^{3}$ Ege University, Agriculture Faculty, Horticulture Department, Izmir, Turkey
}

\begin{abstract}
Characterization of the phenolic compounds of wines from Muscat of Bornova, a native aromatic white grape variety (Vitis vinifera) grown in the Aegean region of Turkey and the influence of terroir (Menderes, Halilbeyli and Kemaliye subregions) on these compounds were investigated. From Muscat of Bornova growing sub regions, Menderes/Izmir has a typical Mediterranean climate at around $90 \mathrm{~m}$ altitude which is located Eagean cost area with a fertile sandy-loamy soil; Halilbeyli/Izmir sub-region is located in inner İmir, close to Manisa with $115 \mathrm{~m}$ altitude with same soil structure of Menderes. Kemaliye/Manisa has a transition climate between Mediterranean and continental climate at about $245 \mathrm{~m}$ altitude. Its soil is pale with a distinct amount of lime $(\sim 30 \%)$ and sandy-loamy, as well. High performance liquid chromatography-diode array dedector (HPLC-DAD) and mass spectrometry (MS) were used for the phenolic compounds analysis. Four flavanols, eight phenolic acids and a flavonol were identified and quantified. It was observed that the total phenolic content in the Halilbeyli sub-region was the highest, followed by the Menderes and Kemaliye sub-regions. Procyanidin B4 was the most abundant flavanol and quercetin-3-O-glucoside was the only flavonol identified in all regions' wines. Sensory analysis was also used to investigate the influences of terroir. Statistically significant (0.05) regional differences were observed. Based upon sensory analysis, the wine obtained from Halilbeyli was darker in color, and had more astringency and bitterness than the others, and was the least popular wine. Kemaliye and Menderes were both preferred due to their better coloring, flavour, less astringency and bitterness attributes.
\end{abstract}

\section{Introduction}

Terroir is one of the most important factors affecting the organoleptic characteristics of grapes and, consequently, its wines. The term covers the topography, climate, and soil, which are the whole natural environment of the vine, even cultural practices included this [1].

Turkey is the sixth largest grape producing country in the world with a production of 4.2 million tons per year. The first traces of viticulture and winemaking in Anatolia date back 7000 years. Muscat of Bornova is a native aromatic white wine grape variety (Vitis vinifera) grown in the Aegean region, mainly in the Menderes/Izmir and Kemaliye/Manisa sub-regions. This grape variety is used for the production of one of the highest quality aromatic white wines in Turkey [2].

Both color and astringency derive from phenolic compounds which are especially concentrated in the stems, seeds, and skins [3]. Wine phenolic compounds fall into one of two major classes. Non-flavonoids are comprised of hydroxybenzoates, hydroxycinnamates and stilbenes. Flavonoids include flavonols (e.g., quercetin, myricetin), flavan-3-ols (e.g., catechin, epicatechin), as well as polymers of the latter defined as procyanidins in white wines. These phenolic compounds of wine have attracted much interest due to their antioxidant properties and their potentially beneficial effects on human health [4]. These compounds are also responsible for browning reactions in grapes and wines. Phenolic compounds (coumaric acid derivatives, flavans) play an important role in the oxidative reactions stimulated by iron, copper and enzymes, and they also involve aldehydes, amino acids and proteins which can occur in musts and wines causing flavour alterations [3].

Soil and climate are the two main factors taken into consideration with regard to the influence on wine quality [5]. The effects of altitude [6], water availability [7], slope [8], and exposure [9] on vine have been evaluated for some important cultivars. However, the influence of the environmental factors on the phenolic characteristics of Muscat of Bornova grown in Turkey has not been studied, yet.

The present research analyses the general composition and phenolic profile of the Muscat of Bornova grape variety grown in the Menderes/Izmir and Kemaliye/Manisa sub-regions to determinate the influence of terroir.

\section{Materials and methods}

Chemicals. All chemicals used in this work were of analytical grade. Milli-Q water (Millipore, Bedford, MA) was used in all the work. HPLC-grade acetonitrile and formic acid were purchased from (Merck, Darmstadt, Germany). Flavan-3-ols [i.e. (+)-catechin, and (-)-epicatechin], procyanidin dimers (B1 and B2), phenolic acids (gallic, 


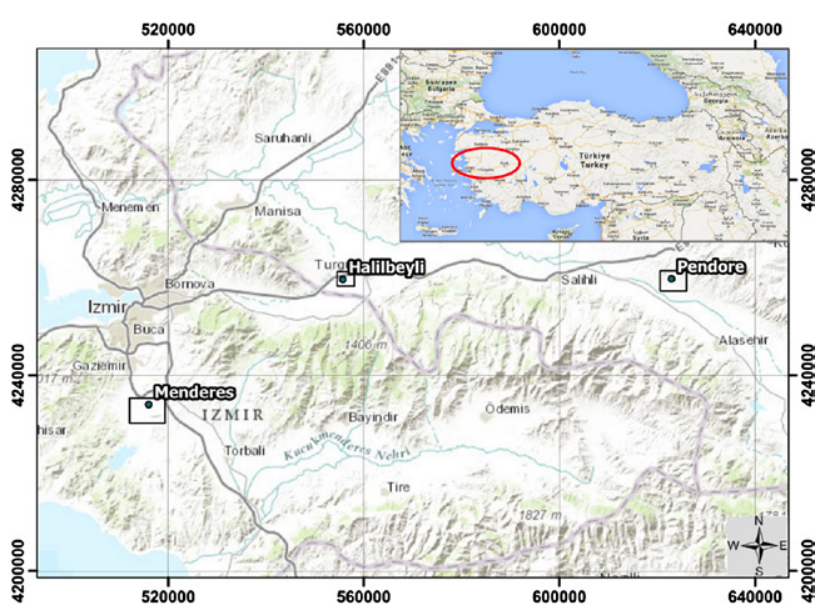

Figure 1. Locations of studied Muscat of Bornova Grape vineyards in Turkey.

protocatechuic, vanillic, caftaric and ferulic acids) and flavonols (the 3-glucoside of myricetin, quercetin, kaempferol) were purchased from Sigma-Aldrich.

Grape cultivation. All vineyards were planted with $V$. vinifera $\mathrm{L}$. cv. Muscat of Bornova vines. The similar management, such as irrigation, fertilization, soil management, pruning, and disease control were conducted in the vineyards.

The terroirs in the study are shown in Fig. 1.

The first vineyard located in Menderes is close to the Aegean sea with the coordinates, latitude (North) $38^{\circ} 14^{\prime} 33^{\prime \prime}$ and longitude (East) $27^{\circ} 9^{\prime} 42^{\prime \prime}$; its altitude is $82 \mathrm{~m}$. The soil type of this vineyard is "sandy-loamy soil" in general. The climate is mild.

With a sea level of $115 \mathrm{~m}$ altitude, the Halilbeyli/Izmir sub-region is the second area, located in inner Izmir. It is close to Manisa and has a sandy-loamy soil. The coordinates of Halilbeyli vineyard are latitude (North) $38^{\circ} 28^{\prime} 56^{\prime \prime}$ and longitude (East) $27^{\circ} 38^{\prime} 20^{\prime \prime}$. The climate is mild, similar to Menderes terroir.

The third vineyard in Kemaliye is in a climate transition area which experiences continental climate features; its coordinates, latitude (North) $38^{\circ} 28^{\prime} 36^{\prime \prime}$ and longitude (East) $28^{\circ} 24^{\prime} 33^{\prime \prime}$, the altitude is $245 \mathrm{~m}$. Soil is mostly "sandy-loamy and calcareous". The meteorological info is shown in Table 1.

In addition to meteorological data, the hours of sunshine are similar in all terroirs: about $8 \mathrm{~h}$ on average per day for a year and $10.5 \mathrm{~h}$ on average per day for the growth period from April to August (the average long time period data obtained from local meteorological stations).

Soil analysis. Soil samples were taken from the center of each sub plot at depths of 30-60 cm at the end of July (Veraison). Particle size distribution was determined by the Bouyoucos hydrometer method [10]. For microelement analysis (Fe and $\mathrm{Zn}$ ), samples were prepared with extraction solution DTPA, diethylene triamine pentaacetic acid and measured using an automatic absorption spectrophotometer by the method of Lindsay and Norwell, 1978 [11]. Total P was determined by the method of Olsen and Sommer (1982) [12]. For the extraction of K, Ca, and Mg, $1 \mathrm{~N}$ Ammonium acetate $(\mathrm{pH}=7)$ used with the method "Kacar (1984)" [13]. The extracts were analyzed directly with the automatic absorption spectrophotometer. $\mathrm{pH}$ and $\%$ total salt measured in saturation mud with $\mathrm{pH}$-meter and Wheatstone bridge [14].

Winemaking. Healthy grapes from cv. Muscat of Bornova were manually harvested in the Menderes, Halilbeyli and Kemaliye (Pendore) vineyards and transported to the Experimental Winery at the Department of Food Engineering, University of Cukurova. Destemmed grapes were then crushed and $\mathrm{SO}_{2}$, pectic enzymes $(3 \mathrm{~g} / \mathrm{hl})$ (Lafase Fruit, Laffort Enologie, France) were added. The must was stored for $12 \mathrm{~h}$ at $10^{\circ} \mathrm{C}$ for particle precipitation. The temperature of the must was set to $19^{\circ} \mathrm{C}$ and inoculation was carried out at $20 \mathrm{~g} / \mathrm{hl}$ after rehydration

Table 1. Meteorological parameters of different terroirs.

\begin{tabular}{lcccccc}
\hline \multicolumn{1}{c}{ Parameters } & \multicolumn{2}{c}{ Menderes } & \multicolumn{2}{c}{ Halilbeyli } & \multicolumn{2}{c}{ Kemaliye } \\
\hline & $\mathbf{2 0 1 3}$ & $\begin{array}{l}\text { Long Time } \\
\text { Period }\end{array}$ & $\mathbf{2 0 1 3}$ & $\begin{array}{l}\text { Long Time } \\
\text { Period }\end{array}$ & $\mathbf{2 0 1 3}$ & $\begin{array}{l}\text { Long Time } \\
\text { Period }\end{array}$ \\
\hline$T_{\max }\left({ }^{\circ} \mathrm{C}\right)$ & 30 & 29.9 & 30 & 29.9 & 30.4 & 29.8 \\
$T_{\min }\left({ }^{\circ} \mathrm{C}\right)$ & 17.1 & 16.6 & 15.6 & 16.5 & 15.2 & 15.6 \\
$T_{\text {avg. }}\left({ }^{\circ} \mathrm{C}\right)$ & 23.6 & 23.2 & 22.8 & 22.6 & 23 & 23.2 \\
$\mathrm{RH}$ avg $(\%)$ & 50.5 & 52.3 & 54.3 & 47.1 & 52 & 46.6 \\
Rainfall $(\mathrm{mm})$ & 909.6 & 772.7 & 786.6 & 808.5 & 421.6 & 421.3 \\
$\mathrm{SR}\left(\mathrm{WH} / \mathrm{m}^{2}\right)^{*}$ & & 553782 & & 542875 & & 587465 \\
\hline
\end{tabular}

$T_{\max }$, maximum temperature; $T_{\min }$, minimum temperature; $T_{\text {avg }}$, average temperature; RH avg., average relative humidity; SR, Solar Radiation. All meteorological data were provided by the Meteorological weather stations placed in Izmir and Manisa. $T, T_{\text {min }}, T$, RHavg data represents the period between 1 st April-30th August. Rainfall data represents whole year. For Menderes 2001-2013 Adnan Menderes station data, for Halilbeyli 1984-97 and 2012-2013 Kemalpasa station data, for Kemaliye 1975-2013 Alasehir station data used for "Long time period" data.

*Solar radiation values obtained from ArcGIS 10.2 software. 
of the yeast (Zymoflore X 5, Laffort Enologie, Fransa) in warm water for $30 \mathrm{~min}$. Fermentation took place in stainless steel tanks at $19-20^{\circ} \mathrm{C}$. After fermentation, the wines were cooled to $5^{\circ} \mathrm{C}$ and stored for a day (stabilisation). The wines were bottled and stored at $15^{\circ} \mathrm{C}$ for four months prior to analysis.

Standard chemical analysis. Titratable acidity, $\mathrm{pH}$, and reducing sugar analyses were performed on the wines [15]. Additionally, the ethanol content, volatile acidity, free and bound $\mathrm{SO}_{2}$, color analysis were determined for each wine [15-18].

HPLC analysis of phenolic compounds. Each sample was first filtered through a $0.45 \mathrm{~mm}$ Nylon filter and then injected to the Agilent 1100 HPLC system (Agilent Technologies, Palo Alto CA-USA) operated by Windows NT based ChemStation software. The HPLC equipment was used with a diode array detector (DAD). The system consisted of a binary pump, a degasser and an auto sampler. The column used was a Phenomenex reversed-phase C-18 column $(4.6 \mathrm{~mm} \times 250 \mathrm{~mm}, 5 \mu \mathrm{m})$ (Torrance, CA). The identification and assignment of each compound was performed by comparing their retention times and UV spectra to authentic standards and also confirmed by an Agilent 6430 LC-MS/MS spectrometer equipped with an electrospray ionization source. The electrospray ionization mass spectrometry detection was performed in negative ion mode with the following optimized parameters: capillary temperature $400^{\circ} \mathrm{C}$, capillary voltage $-3 \mathrm{~V}$, nebulizer gas flow $1.75 \mathrm{~L} / \mathrm{min}$, desolvation gas flow $1 \mathrm{~L} / \mathrm{min}$, and spray voltage $5 \mathrm{kV}$. Analysis was performed in negative mode. The HPLC determination and quantification of the main phenolics were carried out as described in Kelebek et al. (2009) [19]. Identification of the main phenolic compounds was performed by comparing their retention times and UV spectra to authentic standards and also confirmed by HPLC-MS analysis. Their quantification was performed in triplicate using an external standard calibration curve for each compound. Quantification of non-commercial compounds was made using the calibration curves and response factors of a structurally closer compound such as procyanidin B1 for the procyanidin B3 and B4; caffeic acid for cis and trans-caftaric acids; and p-coumaric acid for cis and trans-coutaric acids. Calibration curves were obtained using the commercial standards in the concentrations range normally present in enological products (approximately 1-200 $\mathrm{mg} / \mathrm{l}$ ), the obtained regression coefficients $\left(\mathrm{R}^{2}\right)$ were above 0.992 in all cases.

Sensory analysis. Wines were evaluated using the flavor profile analysis [20]. The panel was composed of 11 assessors from our department, previously trained in wine sensory evaluation techniques. The panel generated descriptors for the flavor profile analysis. 7 odour descriptors ("Floral", "Lavender", "Linden", "Citrus", "Tree Fruits", "Tropic", "Sweet-vanilla"), 10 palate descriptors ("Floral", "Citrus", "Tree Fruits", "Tropic" aromas; tastes as "Sweet", "Sour", "Bitter" and qualifications as "Body", "Duration of flavour" and at last but not least "Overall liking") and a visual descriptor (Color) were established. Evaluation sessions took place in a sensory room, at ambient temperature under daylight in our department. For each wine obtained from different sub-regions, panellists evaluated each descriptor on a horizontal unstructured scale of $10 \mathrm{~cm}$. The marks given for each descriptor by all the panellists were summed and an average date was used for a spider web diagram.

Statistical analysis. The statistical analysis used for the data analysis was one-way analysis of variance (ANOVA) to test the effects of terroir. Duncan's multiple-range tests were used to compare the significant differences of the mean values with the family error rate held at 0.05 . The statistical analyses were performed using SPSS statistics software version 18.0 (SPSS Inc., Chicago, IL, USA).

\section{Results and discussion}

Soil composition and properties. Soil is a very important component of terroir. Knowing the soil properties will help determine its effects on Muscat of Bornova grapes and wines. Soil parameters of studied sub-regions is given in Table 2.

Soil texture affects moisture availability to the plant due to its moisture retaining capacity. All studied terroirs have similar soil texture, defined as sandy-loamy. Fertility of vineyard soil directly affects vine vigour and metabolism. In turn, it affects the metabolism of the grapes and its wines. As evidenced by the soil analysis results, the most fertile soil belongs to Menderes, followed by Halilbeyli and then Kemaliye due to the nitrogen, phosphor and organic matter levels (\%) which are the most effective factors on vine vigour. Potassium has been associated with grape composition and wine quality, and its presence appears to

Table 2. General composition and properties of the studied Muscat of Bornova vineyard soils.

\begin{tabular}{lccc}
\hline Texture & Menderes & Halilbeyli & Kemaliye \\
\hline $\mathrm{P}_{2} \mathrm{O}_{5}(\mathrm{mg} / \mathrm{kg})$ & 2.76 & 2.13 & 1.12 \\
$\mathrm{~K}_{2} \mathrm{O}(\mathrm{mg} / \mathrm{kg})$ & 456 & 107 & 125 \\
$\mathrm{Fe}(\mathrm{mg} / \mathrm{kg})$ & 16 & 42 & 4.26 \\
$\mathrm{Zn}(\mathrm{mg} / \mathrm{kg})$ & 0.89 & 1.22 & 0.38 \\
$\mathrm{Mn}(\mathrm{mg} / \mathrm{kg})$ & 18 & 29.02 & 16.29 \\
$\mathrm{Cu}(\mathrm{mg} / \mathrm{kg})$ & 4 & 4.05 & 0.31 \\
$\mathrm{MgO}(\mathrm{mg} / \mathrm{kg})$ & 380 & 20 & 161 \\
$\mathrm{Ca}(\mathrm{mg} / \mathrm{kg})$ & 8330 & 980 & 4802 \\
$\mathrm{Na}(\mathrm{mg} / \mathrm{kg})$ & 115 & 37 & 38 \\
$\mathrm{~N}(\%)$ & 0.084 & 0.062 & 0.028 \\
Organic Matter & 1.81 & 1.29 & 1.08 \\
$(\%)$ & & & \\
$\mathrm{Salt}$ & 0.059 & 0.016 & 0.016 \\
$\mathrm{pH}$ & 7.61 & 6.12 & 7.82 \\
$\mathrm{Lime}(\%)$ & 11.5 & 0.5 & 30.2 \\
\hline $\mathrm{P} O$
\end{tabular}

P: Olsen;N: Kjeldhal; Na,K, Ca, Mg: 1 N NH $4 \mathrm{OAc}$; Fe, Zn, Cu, Mn; DTPA. 
be linked with acids and $\mathrm{pH}$. Musts, which contain high amounts of $\mathrm{K}$, also tend to have high $\mathrm{pH}$ and high malate, although during vinification malate may drop and $\mathrm{pH}$ may increase even further [21]. Menderes vineyard has a greater amount of potassium than Halilbeyli and Kemaliye vineyards. Sea water carried by winds brings $\mathrm{Na}, \mathrm{Mg}$ and $\mathrm{Ca}$ elements to the innerland, thus it is understandable that Menderes has the highest amounts of these micronutrients, followed by Halilbeyli and Kemaliye according to the proximity to the Mediterranean Sea. According to Lindsay and Novell (1978) $2.5-4.5 \mathrm{mg} / \mathrm{kg}$ Fe was seen appropriate for vineyards [11]. Halilbeyli has the highest amount of $\mathrm{Fe}$, followed by Menderes and Kemaliye. This also determines the color of the soil and thus, the amount of light reflected from ground surface to the grapes. Additionally, the lighter soil color of Kemaliye (also related to high lime levels) provides more light to grape clusters including the shaded parts of the canopy. Micro elements $\mathrm{Cu}, \mathrm{Zn}, \mathrm{Mn}$, are useful in typical concentrations $(0.1-100 \mathrm{mg} / \mathrm{kg})$, but exhibit toxic effects at higher concentrations [22]. The amount of metal ions such as $\mathrm{Fe}$, and $\mathrm{Cu}$ is higher in the soil of Halilbeyli, followed by Menderes. This can affect the amount of polyphenoloxidase which has copper ions in its structure. There are no salt or $\mathrm{pH}$ problems in the vineyards that were studied. The lime content of the vineyards gives a great difference to the terriors. Kemaliye has a $30 \%$ lime content, followed by Menderes $(11.5 \%)$ and Halilbeyli $(0.5 \%)$. In literature it is reported that such soils rich with lime tend to give "high quality wines" with better color, body and aroma intensity with a higher alcohol content due to more sugar from the grapes $[23,24]$.

General composition of the wines. Total acidity of Muscat of Bornova wines was found between 6.6 and $6.9 \mathrm{~g} / \mathrm{L}$. Kemaliye was had the highest $(6.9 \mathrm{~g} / \mathrm{L})$, followed by Halilbeyli $(6.7 \mathrm{~g} / \mathrm{L})$ and Menderes $(6.6 \mathrm{~g} / \mathrm{L})$. Day-night temperature difference is known to be effective on acidity. Also, higher altitudes tend to be contribute to more acidic wines. (Ribéreau-Gayon et al. 2000). Wines from the Menderes sub-region presented the highest drymatter and density of the three sub-regions, which is closely related to the mineral content of the soil, followed by Halilbeyli and Kemaliye soils. Among the colorimetric values, $L$ value shows the approximate measure of lightness, a* and b* coordinates, which represent the red-green colour and yellow-blue colour respectively. A* value was very close in Menderes and Kemaliye, with a negative value, which represents green color. Alternatively, Halilbeyli wine showed a positive value which represents red color. $\mathrm{B}^{*}$ value which represents yellow color in positive values was higher in Menderes (2.65), followed by Halilbeyli (1.41) and at last Kemaliye (0.14). C* (Chroma), which is considered the quantitative attribute of colourfulness was higher again in Menderes (2.92), followed by Halilbeyli (1.43) and Kemaliye (0.323). Hue value, which represents the qualitative attribute of the colour was higher in Halilbeyli with 259.3 value, followed by Kemaliye (154.2) and Menderes (114.8). According to this data, Menderes wine had the most intense color, Kemaliye wine had the lightest color and Halilbeyli wine had a red hue which shows its tendency to browning even after 4 months storage.
Table 3. General composition of the wines of Muscat of Bornova obtained from different sub-regions.

\begin{tabular}{lccc}
\hline & Menderes & Halilbeyli & Kemaliye \\
\hline Density $\left(20^{\circ} \mathrm{C}\right)$ & 0.9910 & 0.9889 & 0.9886 \\
Alcohol $\left({ }^{\circ}\right)$ & $13.1 \pm 0.0$ & $13.2 \pm 0.0$ & $13.0 \pm 0.0$ \\
$\begin{array}{l}\text { Volatile acidity } \\
(\mathrm{g} / \mathrm{L})\end{array}$ & $0.47 \pm 0.04$ & $0.45 \pm 0.00$ & $0.27 \pm 0.04$ \\
$\begin{array}{l}\text { Total acidity } \\
(\mathrm{g} / \mathrm{L})\end{array}$ & $6.6 \pm 0.00$ & $6.7 \pm 0.1$ & $6.9 \pm 0.1$ \\
$\mathrm{pH}$ & & & \\
$\begin{array}{l}\text { Reducing sugar } \\
(\mathrm{g} / \mathrm{L})\end{array}$ & $3.5 \pm 0.0$ & $4.5 \pm 0.1$ & $2.8 \pm 0.1$ \\
$\begin{array}{l}\text { Total } \mathrm{SO}_{2} \\
\text { Free } \mathrm{SO}_{2}\end{array}$ & $13 \pm 0.00$ & $51 \pm 0.00$ & $13 \pm 0.00$ \\
Drymatter $(\mathrm{g} / \mathrm{L})$ & $15.3 \pm 0.2$ & $15.1 \pm 0.3$ & $14.7 \pm 0.3$
\end{tabular}

\begin{tabular}{lccc} 
Color & & & \\
$\mathrm{L}^{*}$ value & $47.02 \pm 0.11$ & $40.16 \pm 0.06$ & $42.44 \pm 0.05$ \\
$\mathrm{a}^{*}$ value & $-0.22 \pm 0.01$ & $0.26 \pm 0.00$ & $-0.21 \pm 0.01$ \\
$\mathrm{~b}^{*}$ value & $2.65 \pm 0.01$ & $1.41 \pm 0.02$ & $0.14 \pm 0.03$ \\
$\Delta \mathrm{C}$ & 2.92 & 1.43 & 0.323 \\
Hue value & 114.84 & 259.29 & 154.23 \\
\hline
\end{tabular}

${ }^{a}$ As tartaric acid equivalent.

Phenolic composition of wines. Phenolic compound concentration in white wines is about $250 \mathrm{mg} / \mathrm{L}$ and it is strongly related to pressing conditions during winemaking $[25,4]$.

A total of thirteen phenolic compounds were identified and quantified in wines obtained with the grape harvested from selected vineyards including 4 flavanols $[(+)$ catechin $\mathrm{m} / z 289\left[\mathrm{M}^{+}\right]$(peak no 1), (-)epicatechin $\mathrm{m} / z 289$ $\left[\mathrm{M}^{+}\right]$(peak no 2), procyanidin B1 m/z $577\left[\mathrm{M}^{+}\right]($peak no 3) and procyanidin B2 $\mathrm{m} / \mathrm{z} 577\left[\mathrm{M}^{+}\right]$(peak no 4)], 8 phenolic acids [gallic acid $m / z 169$ (peak no 5), protocatechuic acid $m / z 153\left[\mathrm{M}^{+}\right]$(peak no 6), cis-caftaric acid $m / z 311$ [100, $\left.\mathrm{M}^{+}\right]$(peak no 7), trans-caftaric acid $\mathrm{m} / \mathrm{z}, 311\left[\mathrm{M}^{+}\right]$(peak no 8), cis-coutaric acid $\mathrm{m} / \mathrm{z} 295\left[\mathrm{M}^{+}\right]($peak no 9), transcoutaric acid $m / z 296\left[\mathrm{M}^{+}\right]$(peak no 10), $p$-cumaric acid $m / z 163\left[\mathrm{M}^{+}\right]$(peak no 11), fertaric acid $m / z 325\left[\mathrm{M}^{+}\right]($peak no 12)], and a flavonol (quercetin-3-O-glycoside $\mathrm{m} / \mathrm{z} 463$ $\left[\mathrm{M}^{+}\right]$(pik no 13)] (Fig. 2).

The results obtained by applying one-way ANOVA revealed that significant differences existed in most of the quantified compounds. There were significant differences in the mean values for the most of these phenolic compounds in wines in relation to terroir, except $p$-coumaric acid.

Menderes sub-region wines had $33.2 \mathrm{mg} / \mathrm{L}$ of flavanols, $99.9 \mathrm{mg} / \mathrm{L}$ phenolic acids, and $137 \mathrm{mg} / \mathrm{l}$ of flavonols; Halilbeyli wines contained 24.4, 124.7, and $151.3 \mathrm{mg} / \mathrm{L}$ of these compounds, respectively, as the last Kemaliye wines had $37.2 \mathrm{mg} / \mathrm{L}$ of flavanols, $55.2 \mathrm{mg} / \mathrm{L}$ phenolic acids, and $97.6 \mathrm{mg} / \mathrm{l}$ of flavonols, respectively. As can be seen from 


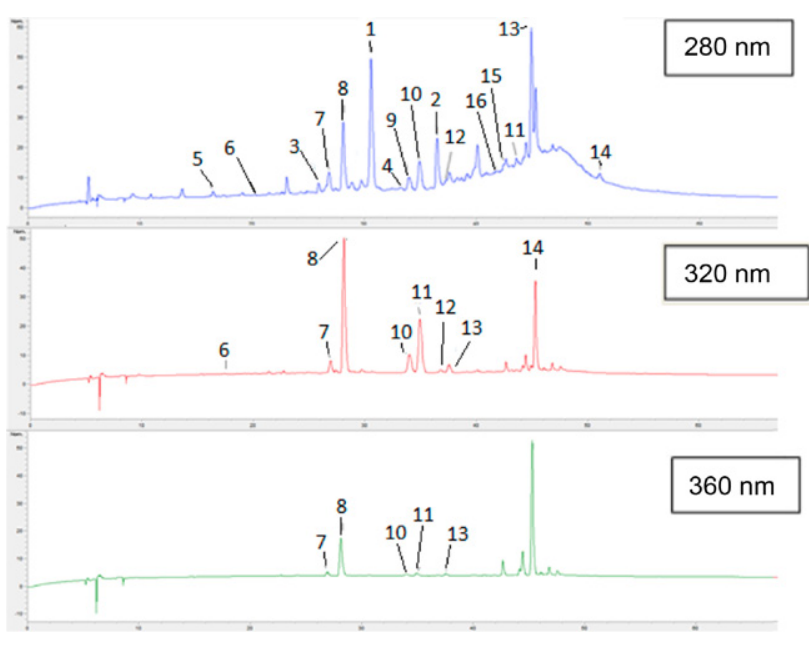

Figure 2. Chromatograms in 280, 320 and $360 \mathrm{~nm}$ of identified Phenolic compounds in wines.

Table 4, the most abundant compound was trans-caftaric acid. The amounts of trans-caftaric acid for Menderes, Halilbeyli and Kemaliye wines were 55, 80 and $39 \mathrm{mg} / \mathrm{L}$, respectively. Secondly trans-coutaric acid concentration followed trans-caftaric acid. Trans-coutaric concentration of Menderes, Halilbeyli and Kemaliye wines were 23.6, 25.3 and $5.8 \mathrm{mg} / \mathrm{L}$, respectively. These two compounds are tartaric acid esters of hydroxycinnamic acids and the main phenol class of must and wine and their content is significantly affected by location. These results were similar in Lampir and Pavlousek's (2013) [26] results. In Moravian Muscat wine (Czech Republic) caftaric acid was reported the most dominant phenolic compound $(37 \mathrm{mg} / \mathrm{L})$, followed by $p$-coutaric acid ( $14 \mathrm{mg} / \mathrm{L})$ and the average content of these compounds was reported as being much lower in Perna a site which is comprised of geological bedrock is limestone ( $8 \mathrm{mg} / \mathrm{L}$ and $3 \mathrm{mg} / \mathrm{L}$, respectively) [26]. This can also be the explanation of lower amounts of caftaric and coumaric acids in Kemaliye which has a lime rich soil type as well. The average caftaric acid content of different white wines was reported and ranged from 8 to $54 \mathrm{mg} / \mathrm{L}$ [26]. The caftaric and coutaric acid content of the wines of muscat Lefko cultivar (from the Island of Samos) was reported as in the range of 2.5-43.7 and 4-24.4, respectively [27]. Sen and Tokatlı (2014) studied the phenolic profile of the wines of important Anatolian grape varieties [28]. In relation with our study, they reported that Muscat white wines could be distinguished from the other white wines with higher hydroxycinnamic acid content (Narince

Table 4. Phenolic composition of the wines of Muscat of Bornova obtained from different sub-regions (mg/L).

\begin{tabular}{|c|c|c|c|c|}
\hline Phenolic compounds (mg/L) & Menderes & Halilbeyli & Kemaliye & $\mathbf{F}$ \\
\hline \multicolumn{5}{|l|}{ Flavanols (Flavan 3-ols) } \\
\hline Procyanidin B1 & $6.62 \pm 0.1^{\mathrm{a}}$ & $4.55 \pm 0^{\mathrm{b}}$ & $3.88 \pm 0.01^{\mathrm{c}}$ & $*$ \\
\hline Procyanidin B4 & $14.87 \pm 0.03^{\mathrm{b}}$ & $10.65 \pm 0.5^{\mathrm{c}}$ & $19.59 \pm 0.01^{\mathrm{a}}$ & $*$ \\
\hline Catechin & $8.37 \pm 0.02^{\mathrm{b}}$ & $6.20 \pm 0.6^{c}$ & $11.16 \pm 0^{\mathrm{a}}$ & $*$ \\
\hline Procyanidin B2 & $3.33 \pm 0.21^{\mathrm{a}}$ & $2.98 \pm 0.3^{\mathrm{a}, \mathrm{b}}$ & $2.61 \pm 0.05^{\mathrm{b}}$ & $*$ \\
\hline Total & 33.19 & 24.38 & 37.24 & \\
\hline \multicolumn{5}{|l|}{ Phenolic Acids } \\
\hline Gallic Acid & $5.10 \pm 0.02^{\mathrm{a}}$ & $3.44 \pm 0^{\mathrm{b}}$ & $2.72 \pm 0.01^{\mathrm{c}}$ & $*$ \\
\hline Protocatechuic acid & $1.40 \pm 0.01^{\mathrm{a}}$ & $1.33 \pm 0.01^{\mathrm{b}}$ & $1.27 \pm 0.05^{\mathrm{b}}$ & $*$ \\
\hline cis-caftaric & $2.74 \pm 0.04^{\mathrm{b}}$ & $3.74 \pm 0.01^{\mathrm{a}}$ & $1.55 \pm 0.01^{\mathrm{c}}$ & $*$ \\
\hline trans-caftaric & $55.02 \pm 0.09^{\mathrm{b}}$ & $80.09 \pm 0.07^{\mathrm{a}}$ & $39.21 \pm 0.02^{\mathrm{c}}$ & $*$ \\
\hline cis-coutaric & $9.78 \pm 0^{\mathrm{b}}$ & $8.74 \pm 0.01^{\mathrm{b}}$ & $2.46 \pm 0^{c}$ & $*$ \\
\hline trans-coutaric & $23.67 \pm 0.04^{\mathrm{b}}$ & $25.30 \pm 0.02^{\mathrm{a}}$ & $5.79 \pm 0.01^{\mathrm{c}}$ & $*$ \\
\hline$p$-coumaric acid & $0.19 \pm 0$ & $0.19 \pm 0$ & $0.19 \pm 0$ & n.s. \\
\hline Fertaric acid & $1.99 \pm 0.05^{\mathrm{a}}$ & $1.90 \pm 0.03^{\mathrm{b}}$ & $1.97 \pm 0.01^{\mathrm{a}}$ & $*$ \\
\hline Total & 99.89 & 124.73 & 55.16 & \\
\hline \multicolumn{5}{|l|}{ Flavonols } \\
\hline Quercetin-3-O-glycoside & $3.88 \pm 0.19^{b}$ & $2.22 \pm 0.28^{c}$ & $5.16 \pm 0.01^{\mathrm{a}}$ & $*$ \\
\hline Genel Toplam & 136.96 & 151.33 & 97.56 & \\
\hline
\end{tabular}


was reported as rich in flavan-3-ol content, Sultaniye was reported as having the poorest phenolic content).

According to a study by Price et al. with Pinot noir wines, caftaric acid in wine was inversely related to cluster sun exposure [29]. The low levels of caftaric acid in wines from sun-exposed clusters appeared to be related to hydrolysis of the tartaric ester. This explanation also conforms with the present study's results. In addition, Halilbeyli and Menderes vines are more vigorous (bigger leaf areas, more shaded clusters) than Kemaliye vines. Caftaric acid concentration is strongly related to the maceration process. Ruzic et al. (2011) reported that macerated 800B coded wine had $53.1 \mathrm{mg} / \mathrm{L}$, which was also reported as equal to the highest concentration found in Spanish table white wine $(53.5 \mathrm{mg} / \mathrm{L})$ [30]. The average concentration of this acid was found to be almost double of what is found in non-macerated ones.

These two phenolic compounds are primarily oxidised and then they initiate browning reactions. They have important health effects as antioxidants but also they increase the potential browning of wines, thus the stability of wine [3]. These two compounds had the highest presence in Halilbeyli wines. This explains the red hue in the colorimetric assessment of Halilbeyli wines, even after 4 months of storage. Kemaliye wines had the lightest color in colorimetric assessments, so they had the least phenolic acid concentration.

Among the flavanols, procyanidin B4 was the most abundant in all wine terroirs. Kemaliye had the highest flavanol content, especially prociyanidin B4, as well. Proantosiyanidins locate in grape seeds and are responsible for the astringency and bitterness of wine. They also participate in chemical and enzymatic oxidative browning reactions in haze formation and interactions with proteins, as well as numerous condensation reactions during wine maturation and aging [31].

Flavonols strongly absorb light in $360 \mathrm{~nm}$ and are generally located in the outer lining of grape skin, it seems that plants produce this matter as a natural sunscreen. Light increases the amount of flavonols [29]. Flavonols are relatively few amounts in Muscat of Bornova wines, because of the production style of the white wines. The ranking of the amount of flavonols in studied wines correlates with the ranking of the solar radiation amount of the vineyards. Gallic and protocatechuic acids are the most important hydroxybenzoic acids occuring in grapes. The contents of hydroxybenzoic acids in wine are strongly dependent on the grapevine variety [32]. Gallic and protocatechuic acids were changed $2.72-5.10 \mathrm{mg} / \mathrm{L}$ and $1.3-1.4 \mathrm{mg} / \mathrm{L}$, respectively. In Moravian Muscat, gallic and protocatechuic acids were reported as 1.2 and 1.4 respectively [26]. Catechin is one of the major flavan-3-ol monomers found in grapes and wine and the range of catechin was found to be $6.2-11.2 \mathrm{mg} / \mathrm{L}$ in Muscat of Bornova. Kemaliye has the highest value followed by Menderes and Kemaliye. In Moravian Muscat wine the average catechin was reported as $13.4 \mathrm{mg} / \mathrm{L}$, while other white varieties ranged in 7.4-10.6 mg/L [26].

Sensory evaluation. To profile the sensory characteristics of wine, wines were evaluated using a Flavor Profile Analysis. Fig. 3 shows the average scores of each wine given by descriptors.

Muscat of Bornova wine can be described as floral and fruity with lavender, linden, tree fruit nuances in nose and

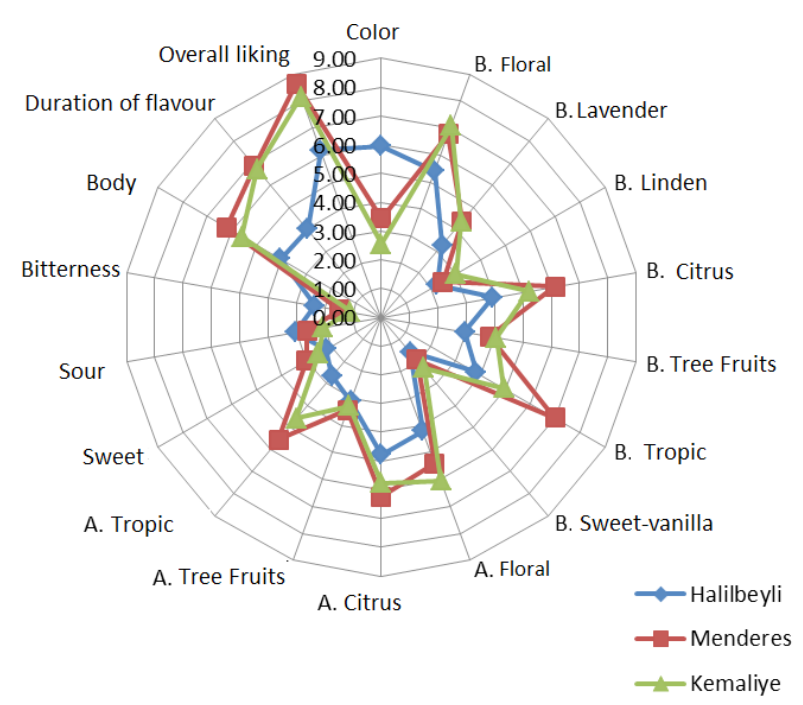

Figure 3. Spider web diagram of flavor profile analysis of Muscat of Bornova wines from three different terroirs. (A) data shows palate descriptors, (B) data shows odor descriptors.

fruity, citrus and tree fruit in mouth with less bitterness properties and pale yellow-light golden yellow tones.

Menderes wine can be described as generally floral and fruity but more tropic in nose; more citrus and tree fruits with a better body and permanence Kemaliye wine is generally floral and fruity but has more floral, linden and tree fruits aromas.

As seen in Fig. 3, Halilbeyli wines had less aromatic properties than Menderes and Kemaliye wines. Bitterness was the highest in Halilbeyli wine with the darkest color property in all studied wines. In general, Halilbeyli wine was the least preferred of the three.

\section{Conclusion}

High performance liquid chromatography-diode array detector and mass spectrometry were used for the phenolic compounds analysis. Four flavanols, eight phenolic acids, and a flavonol were identified and quantified. The results obtained suggested that the total phenolic content of the Halilbeyli sub-region wines was the highest in all studied sub-regions. Procyanidin B4 was the most dominant flavanol; trans-caftaric acid was the most dominant phenolic acid; and quercetin-3-O-glucoside was the only flavonol in all sub-regions. Sensory analysis has also been used in investigating the vineyard location. Based upon sensory analysis, all wines were appreciated. But according to general aroma properties, duration of flavour and color properties Menderes and Kemaliye wines were preferred. According to the results of sensory analysis, the wines obtained from the Halilbeyli sub-region had the most bitter taste, less light color and less aromatic character than the other sub-regions. It was also the least preferred wine. Based on the results of the statistical analysis it can be concluded that the phenolic compounds are significantly affected by the terroir, especially hydroxycinnamic acids. trans-caftaric acid and coutaric acid, catechin and prociyanidin B4 can be used for discrimination of Muscat of Bornova wines terroirs. 
The authors would like to thank The Scientific and Technical Research Council of Turkey (TUBITAK) for financial support of this research (Project No. 112 O 832), SEVILEN and KAVAKLIDERE Wine Companies for providing samples.

\section{References}

[1] C. Van Leeuwen, J.-P.Roby, D. Pernet, B. Bois, Methodology of soil-based zoning for viticultural terroirs. Bulletin de l'O.I.V., 83, 13-29 (2010).

[2] S. Selli, A. Canbas, T. Cabaroglu, H. Erten, Z. Günata, Aroma components of cv. Muscat of Bornova wines and influence of skin contact treatment, Food Chemistry, 94, 319-326 (2003).

[3] R.C. Minussi, M. Rossi, L. Bologna, D. Rotilio, G.M. Pastore, N.Duran, Journal of Molecular Catalysis B : Enzymatic 45, 102-107 (2007).

[4] H. Kelebek, S. Selli, Wine Phenolics: Chemistry, Biosynthesis and Effects on Health. Chapter 16. Ed. Arthur S. Peeters. Nova Science Publishers, Inc. ISBN: 978-1-61470-635-9. (2011).

[5] R.D.A. Prado, M. Yuste-Rojas, X. Sort, C. Andrés-Lacuea, M. Torres, R.M.Lamuela-Raventós, Effect of Soil Type on Wines Produced from Vitis vinifera L. Cv. Grenache in Commercial Vineyards. J. Agric. Food Chem., 55, 779-786 (2007).

[6] N. Mateus, S. Proença, P. Ribeiro, J.M. Machado ve V.D. Freitas, Grape and wine phenolic composition of red Vitis vinifera varieties concerning vineyard altitude. Ciencia y Tecnologia Alimentaria, 3, Issue 2.(2001).

[7] A.G. Reynolds, and A.P. Naylor. Pinot noir and Riesling grape vines respond to water stress duration and soil water-holding capacity. Hort Sci. 29, 1505-1510 (1994).

[8] G. Mazza, L. Fukumoto, P. Delaquis, B. Girard, and B. Ewert. Anthocyanins, phenolics, and color of cabernet franc, merlot, and pinot noir wines from British Columbia. J. Agric. Food Chem. 47, 4009-4017 (1999).

[9] S.E. Spayd, J.M. Tarara, D.L. Mee, and J.C. Ferguson. Separation of sunlight and temperature effects on the composition of Vitis vinifera $c v$. Merlot berries. Am. J. Enol. Vitic. 53, 171-182 (2002).

[10] G.J. Bouyoucos, Hydrometer Method Improved For Marking Particle Size Analysis of Soils. Agronomy J. 54, pp. 464-465 (1951).

[11] W.L. Lindsay, W.A. Norwell, Development of DTPA soil test for zinc, iron, manganese and copper. Soil Sci. Amer. Jour., 42(3),421-428 (1978).

[12] S.R. Olsen, and L.E. Sommers, Phosphorus in Methods of Soil Analysis Part 2. Chemical and Microbiolgial Properties. Agronomy Monograph No. 9. 8 Ed. Page, A. L. Asa-Sssa. Madison, USA (1982).

[13] B. Kacar, Bitki Besleme, Ankara Üniversitesi Ziraat Fakültesi Ders Yayınları, Ankara (1984).

[14] E. Schlichting, H.P. Blume, Bodenkundliches Praktikum : eine Einfuehrung in pedologisches Arbeiten fuer Oekologen, insbesondere Land- und Forstwirte, und fuer Geowissenschaftler. Methods of SoilAnalysis (in German), 209 pp., Parey, Hamburg, Ger., (1966).
[15] OIV, International Organisation of Vine and Wine, Compendium of International Methods of Wine and Must Analysis. Edition 2012, 2 (2012).

[16] C.S. Ough, M.A. Amerine, Methods for Analysis os Musts and Wines, John Willey and Sons, New York, p. 377 (1988).

[17] Y. Glories, La couleur des vins rouges. Conn. Vigne Vin. 18, 253-271 (1984).

[18] P. Ribéreau-Gayon, Y. Glories, A. Maujean, D. Dubourdieau, Handbook of Enology, 2, The Chemistry of Wine and Stabilization and Treatments. John Wiley and Sons Ltd., England (2000).

[19] H. Kelebek, Canbas, A., Jourdes, M., Teissedre, P.L. 2011. HPLC-DAD-MS determination of colored and colorless phenolic compounds in Kalecik karasi wines:Effect of different vineyard locations. Analytical Letters, 44(6), 991-1008. Adana (2009).

[20] M.C. Meilgaard, G.V. Civille, \& B.T. Carr. Sensory Evaluation Techniques (4rd ed.). Boca Raton, FL: CRC Press. (2007).

[21] D.I. Jackson, P.B. Lombard. Environmental and Management Practices Affecting Grape Composition and Wine Quality- A Review. Am. J. Enol. Vitic., 44, No. 4. (1993).

[22] R.E. White, Soils for Fine Wines. Oxford University Press, 24 July (2003).

[23] R. White, L. Balachandra, R. Ed1s, D. Chen, The Soil Component of Terroir, J. Int. Sci. Vigne Vin, 41, $\mathrm{n}^{\circ} 1$, 9-18 (2007).

[24] E.A.C. Constantini, P. Bucell1, S. Priori. VIII International Terroir Congress June 14th-18th, Soave-Italy (2010).

[25] A.L., Waterhouse. Wine Phenolics, Ann. New York Academy of Sciences 957, 21-36 (2002).

[26] L. Lampir and P. Pavlousek, Influence of Locality on Content of Phenolic Compounds in White Wines. Czech J. Food Sci., 31, no 6:619-626 (2013).

[27] S. Karagiannis, A. Economou, P. Lanaridis2000: Phenolic and volatile composition of wines made from Vitis vinifera $c v$. Muscat lefko grapes from the island of Samos. J. Agric. Food Chem. 48, 5369-5375.

[28] I. Sen and F. Tokatl1, Autenticity of wines made with economically important grape varieties grown in Anatolia by their phenolic profile. Food Control, 46, 446-454 (2014).

[29] S.F. Price, P.J. Breen, M. Valallado, B.T. Watson, Am. J. Enol. Vitic. 46, no. 2187-194 (1995).

[30] I. Ruzic, M. Skerget, Z. Knez, M. Runje, Eur Food Res Technol 233, 465-472.

[31] M. Monagas, B. Bartolome, C. Gomez-Cordoves, Updated Knowledge About the Presence of Phenolic Compounds in Wine, Critical Reviews in Food Science and Nutrition, 54, 2, 85-118.

[32] M. Rentzsch, A. Wilkens, P. Winterhalter, Nonflavonoid phenolic compounds. In: MorenoArribas M.V., Polo M.C. (eds): Wine Chemistry and Biochemistry. Springer Science+Business Media, New York :509-527 (2009). 